\title{
Направления развития оптико-электронных систем и приборов в Филиале ИФП СО
} РАН "КТИПМ"

\author{
А.В. Голицын ${ }^{1}$, А. А. Голицын ${ }^{1,2}$, А.О.Лебедев ${ }^{1}$, Б.Н. Новгородов ${ }^{1}$, А.Р. Новоселов ${ }^{1}$, А.Г. Паулиш ${ }^{1,2,3}$, \\ С.М. Чурилов ${ }^{1}$, П.И. Шапор ${ }^{1}$, К.П. Шатунов ${ }^{1}$ \\ ${ }^{1}$ Новосибирский филиал Института физики полупроводников им. А. В. Ржанова СО РАН \\ "Конструкторско-технологический институт прикладной микроэлектроники", \\ 630090, Новосибирск, просп. Лаврентьева, 2/1 \\ ${ }^{2}$ Новосибирский государственный технический университет, \\ 630073, Новосибирск, просп. К. Маркса, 20 \\ ${ }^{3}$ Новосибирский государственный университет, 630090, Новосибирск, ул. Пирогова, 1 \\ тел:+7 (383) 330-6559, факс:+7 (383)330-9106, эл.nочта: paulish63@ngs.ru
}

DOI 10.34077/RCSP2021-88

Оптико-электронные системы (ОЭС) находят всё более широкое применения, в том числе в мобильных интеллектуальных системах, где принятие решения по управлению системы возложено на вычислительное устройство. В связи с этим предъявляются новые требования на основные параметры ОЭС. Среди них - разработка новых эффективных программно-аппаратных комплексов с повышенной глубиной обработки информации, существенное снижение массогабаритных параметров и энергопотребления.

Любой оптико-электронный прибор или канал содержит основные функциональные элементы: оптическая система (ОС), фотоприёмное устройство (ФПУ), система электронной обработки сигналов ФПУ (ЭОС), средство визуализации или отображения информации. Основными элементами, определяющими качество изображения, являются ОС и ФПУ. Современные объективы, обеспечивающие изображение в плоскости матрицы ФПУ необходимого качества, занимают до 90\% массогабаритного параметра ОЭС. Попытка ахроматизации оптических систем в рабочем спектральном диапазоне кремниевых ФПУ или ЭОПов поколения 2+,3 приводит к усложнению ОС, ухудшающему массогабаритные параметры и светопропускание. Филиал ищет решение данной проблемы за счёт использования жидкостных оптических компонентов. Известно, что оптические свойства жидкостей могут плавно регулироваться изменением их состава, что позволяет уменьшить количество твёрдых оптических компонентов, увеличить пропускание ОС, повысить её ахроматичность. Это приведёт к созданию компактных гиперспектральных телевизионных камер прямого, без сканирования, наблюдения. Использование жидкостных линз с быстро перестраиваемой кривизной поверхности открывает новые возможности функционирования ОЭС: быстрая (менее 15 мс) перефокусировка во всём диапазоне фокусировки, получение изображение с неограниченной глубиной резкости и т.п.

Быстрое развитие технологий ФПУ повышает требования не только к ОС, но и к электронной системе обработки сигналов с ФПУ. Возрастают требования к её быстродействию, объёму вычислений, снижению энергопотребления. Перспективным направлением в этой области является использование систем, созданных на парадигме реконфигурируемых высокопроизводительных параллельных вычислений с малым энергопотреблением.

Активно-импульсные системы (АИС), помимо решения военно-прикладных задач, находят широкое применение в гражданских технологиях. Такие системы являются носимыми, поэтому одним из главных требований является снижение массогабаритных параметров и цены. В Филиале разработан способ активно-импульсного видения с электронным затвором на ПЗС фотоприёмнике. Данный способ основан на оригинальной методике управления фотоприёмником, позволяющей наблюдать несколько откликов лазерного излучателя в одном кадре без потери кадровой частоты. Экспериментальные исследования показали реализуемость способа в условиях дыма и тумана.

В последнее время бурно развиваются технологии управления роботизированными наземными и летательными аппаратами, например, беспилотными летательными аппаратами (БПЛА). В данных технологиях ОЭС используются не только для передачи изображения с видеокамеры БПЛА операторупилоту в режиме реального времени, но и сама система управляет движением аппарата в автономном режиме, без пилота и без использования спутниковых навигационных систем. Использование технического зрения освобождает внимание пилота и является наиболее помехозащищённым способом управления. Здесь требуется соблюсти баланс между производительностью системы, её массогабаритными параметрами и энергопотреблением. Система технического зрения должна обеспечивать надёжное управление полётом БПЛА и не должна ухудшать полётные характеристики БПЛА, такие как дальность и продолжительность полёта. 